\title{
EXPLORING THE PRINCIPAL TEACHINGS OF KHALWATIAH SYEKH YUSUF TARIQAH IN SOUTH SULAWESI
}

\author{
Muhaemin Latif \\ Fakultas Ushuluddin dan Filsafat \\ UIN Alauddin Makassar \\ Jln H.M.Yasin Limpo No. 36 Samata Gowa \\ Email: muhaemin.latif@uin-alauddin.ac.id
}

\begin{abstract}
This article discusses the principal teachings of Khalwatiah Syekh Yusuf tariqah in South Sulawesi. This tariqah is one of the leading tariqahs in the region since its emergence in the seventeenth century. Khalwatiah Syekh Yusuf has influenced the Muslim's understanding concerning sufism issues. The researcher employs qualitative as a method of research. The research suggests that Khalwatiah Syekh Yusuf is the integration of different tariqahs which were obtained by Syekh Yusuf during his intellectual journey. The principal teachings of Khalwatiah Syekh Yusuf can be drawn into three elements. They are the concept of inner purity, the understanding of God, and the meaning of insan kamil. These three principal teachings become the foundation of this tariqah as well as become it's characteristic. Although Syekh Yusuf studied from different Sufis, especially from Ibnu Arabi's thought, this tariqah is strongly associated with Asyariyah theology that led to this tariqah be a moderate tariqah.
\end{abstract}

Keywords: Khalwatiah, Syekh Yusuf, Tariqah, Inner Purity, Insan Kamil 


\section{Introduction}

Khalwatiah Syekh Yusuf tariqah (sufi order) is a leading sufi order in South Sulawesi. Martin van Bruinessen noted that this tariqah emerged around the seventeenth century where Syekh Yusuf al-Taj al-Khalwati al-Makassari (1626-1699) is believed as the main figure behind this tariqah. ${ }^{1}$ Therefore, the name of this tariqah has been associated with his name. People in Makassar contend that Syekh Yusuf not only as of the forefront sufi who affiliated with the tariqah ${ }^{2}$ but also as a legend of Moslem story who can be a medium to build a closed relationship between human and God. This can be seen, as far as the researcher observed, several people in everyday who are from different backgrounds and motives came to visit Syekh Yusufs tomb asking for blessing and praying to the God in the site.

The popularity of Syekh Yusuf among the Makassarese is getting stronger when the local government perpetuated his name as the name of the street as well as become the mosque name in Gowa region. Moreover, the Indonesian government appreciated Syekh Yusuf through entitling him as one of the national heroes in the country in 1995 during the regime of the former Indonesian President, Megawati Sukarno Puteri. ${ }^{3}$ Interestingly, the track record of

${ }^{1}$ See Martin van Bruinessen, Kitab Kuning, Pesantren dan Tarekat: Tradisi-Tradisi Islam di Indonesia (Bandung: Mizan, 1995), p. 286.

2A. Ginanjar Sya'ban, "Sanad Syaikh Yusuf al-Makassar atas Tarekat Syaihul Akbar Ibnu Arabi”, unpublished writing, Bogor, 2016.

${ }^{3}$ Syahrir Kila, "Syekh Yusuf: Pahlawan Nasional Dua Bangsa Lintas Benua" Walasuji, 9 (2), 2018, p.247. 
Syekh Yusuf al-Makassar had certainly crossed the archipelago. He was also being the hero in Sri Lanka and South Africa regarding his ability to propagate Islam to those countries. He was also regarded as the prominent ulama from the archipelago who had introduced the freedom rights and equality for the people especially in line with colonialism or imperialism around the seventeenth century. ${ }^{4}$ Consequently, in 1994, Nelson Mandela, the liberation leader of South Africa, specifically commemorated 300 years of Syekh Yusuf's arrival in Cape Town. This historical commemoration has attracted the eye of international attention regarding his role in bringing equality and equity among the human being. ${ }^{5}$

Apart from his popularity and nobility, the legacy of Syekh Yusuf that should be taken into account is the existence of Khalwatiah tariqah in South Sulawesi. This tariqah has been maintained by his followers until recent days. In relation to the Khalwatiah sufi order, the Khalwatiah Syekh Yusuf is not the only khalwatiyah tariqah played in South Sulawesi. ${ }^{6}$ As contended by Martin, there are two different khalwatiah tariqah exist in South Sulawesi, Syekh Yusuf tariqah and Sammaniah tariqah. The last-mentioned is strongly related to Abd Karim Samman, a Madinah Sufi, who had many students

${ }^{4}$ See Abu Hamid, Syekh Yusuf: Seorang Ulama, Sufi dan Pejuang (Jakarta: Yayasan Obor Indonesia, 2005), p. 84.

${ }^{5}$ Erwiza Erman, "Remembering and Forgetting: The History of Syekh Yusuf Struggle for Human Rights", Heritage of Nusantara: International Journal of Religious Literature and Heritage, 1 (1), 2012, p.99.

${ }^{6}$ Achmad Ubaedillah, "Khalwatiah Samman Tarekat in South Sulawesi, Indonesia (1920-1998): Exercising Authority in an Era of Change," Asian Journal of Social Science, 24: 2 (2014). 
from Indonesia, who further introduced Sammaniah tariqah across the country. ${ }^{7}$ Although both tariqah has similar names, their rituals and principals are different. For example, if the Khalwatiah Syekh Yusuf followers slow their voice when reciting dzikr, the Khalwatiah Samman loud their voice until they feel ecstatic. In addition, the system of the Khalwatiah Syekh Yusuf tariqah tends to be decentralized where every adherents of this tariqah has the freedom to do their rituals. In other words, there is no a certain place for adherents to perform driker as Khalwatiah Samman does it. Syekh Yusuf tariqah followers may perform their dzikr in their own homes. ${ }^{8}$

Tracing back the mode of Khalwatiah Syekh Yusuf tariqah is an interesting issue that needs to be addressed in the studies of tariqah, especially in South Sulawesi. Its emergence cannot be separated from the intellectual voyage of Syekh Yusuf. Some are of the opinion that Syekh Yusuf tariqah is a mixture of many different tariqahs. During his intellectual journey, Syekh Yusuf learned many orders from different mursyids, such as the Naqsyabandiah, Qadiriyah, Syattariyah, Alawiyah, and Khalwatiyah. Martin also stated that Syekh Yusuf had entered the Dasuqiyah, Syadziliyah, Chistiyah, Aydarusiyah, Ahmadiyah, Madariyah, Kubrawiyah, and many

${ }^{7}$ See Martin van Bruinessen, "The Tariqa Khalwatiah in South Celebes" in Harry A. Poeze en Pim Schoorl (eds), Excursies in Celebes. Een bundle bijdragen bij het afscheid van J. Noorduyn...(Leiden: KITLV Uitgeverij, 1991), p. 251. 286.

${ }^{8}$ See Martin van Bruinessen, Kitab Kuning, Pesantren dan Tarekat, p. 
other orders. ${ }^{9}$ Once he returned to Archipelago, he officially names his order as khalwatiyah and his adherents add it as Khalwatiah Syekh Yusuf. So, the principal teachings of Khalwatiah Syekh Yusuf are considered as the creation of Syekh Yusuf after learning many orders during his intellectual journey, especially in Mecca and Medinah. Due to his extensive knowledge of sufi orders, he was authorized by many mursyids to teach the orders.

Although numerous studies were undertaken by the researcher regarding Syekh Yusuf, this article will mainly focus on exploring the principal teachings of Khalwatiah Syekh Yusuf considering his tariqah tend to be a unique model compared to the others. I believe this specific issue has not been widely discussed by the researchers. Before going to discuss in detail his principal teachings, the author will firstly introduce Syekh Yusuf al-Makassary as the prominent sufi across the country.

\section{Research Methodology}

This paper is based on the research conducted in 2019. It employed a qualitative research methodology. To obtain data or information, the researcher conducted a participatory observation by joining several dzikr meetings that frequently held on Thursday night in the house of Puang Makka, who is the mursyid of Khalwatiah Syekh Yusuf. Besides, the researcher also undertook some interviews with

\footnotetext{
${ }^{9}$ Martin van Bruinessen, "The Origin and Development of Sufi Orders (Tarekat) in Southeast Asia,", Studia Islamika 1: 1 (1994): p.11
} 
the mursyid of Syekh Yusuf tariqah as well as five followers of this order to get an insight into this issue. Besides, the researcher also did focus group discussion (FGD) among the followers to get comprehensive information regarding the core teaching of Khalwatiah Syekh Yusuf sufi order. In this sense, the researcher picked up five followers of the order. Moreover, the researcher collected documents such as books, journals, internet sources, and unpublished research relating to Syekh Yusuf and his core teaching, particularly on sufism. All these data and information collected through the triangulation method. The researcher summarized and categorized the data through thematic analysis.

\section{Results and Discussion}

Although there are many perspectives regarding the sufi's birth, the historians believe that Syekh Yusuf was born on the $3^{\text {rd }}$ of July 1626 in Moncongloe, Gowa. ${ }^{10}$ He was originally coming from the noblemen where his father is stated as one of the kings in Gowa kingdom. His father's name I Manga'rangi Daeng Manrabbia Sultan Alauddin (Gowa King XIV) and his mother is Aminah who is the daughter of Dampang Ko'mara. During his childhood, Syekh Yusuf spent his life in the palace of Gowa Kingdom. Although some think that Syekh Yusuf is not the biological

${ }^{10}$ Mustapha Keraan, Muhammad Haron, "Selected Sufi Texts of Shaykh Yusuf: Translations and Commentaries", Thdskrif Vir Letterkunde, 45 (1), 2008, p.101 
son of the King but he was treated as the nobleman. ${ }^{11}$ His first teacher is Daeng ri Tasammang, a local Qur'an teacher. He then studied Arabic language, fiqh, theology, and sufism under the guidance of the Arab teacher who lived in Bontoala, a subdistrict in the Makassar region. At the age of 15, he pursued his studies in Cikoang, a famous place for studying Islam, especially sufism discipline. He directly learned from Jalal alDin al-Aidid who was believed as the sufi master from Aceh. Jalaluddin, as contended by Azra, traveled a lot of regions, such as Kutai, before he resided in Cikoang, Takalar. ${ }^{12}$

Due to the strong curiosity toward Islamic knowledge, Syekh Yusuf left Makassar and went to Arabia, as the main center of Islam, in September 1644. As stated by the scholars, Makassar is geographically a strategic place to connect with international trade. ${ }^{13}$ It was regarded as the front gate to enter the east part of Indonesia. Some international traders came to Makassar to do their business with the big boats. This remarkable opportunity benefitted Syekh Yusuf to travel with the businessman, especially to the middle east. He initially traveled to Banten where an Islamic kingdom existed. He built an intimate relationship with the prince of Banten king, Prince Surya who is the successor of Banten King and popularly

${ }^{11}$ See Abu Hamid, Syekh Yusuf: Seorang Ulama, p. 86.

${ }^{12}$ Azyumardi Azra, Jaringan Ulama Timur Tengah dan Kepulauan Nusantara Abad XVII dan XVIII: Akar Pembaruan Islam Indonesia (Jakarta: Kencana, 2007), p. 261.

13 Mattulada, Menyusuri Jejak Kehadiran Makassar Dalam Sejarah (Yogyakarta: Ombak, 2011), p. 18-19. 
called Sultan Ageng Tirtayasa. ${ }^{14}$ Afterward, Syekh Yusuf traveled to Aceh. In this region, he studied qadiriyah tariqah from the family of Nur al-Din al-Raniry. Having got permission to teach this tariqah he continued his intellectual journey to Gujarat, India. Many believed that Syekh Yusuf met Syekh Nur al-Din al-Raniry in Gujarat. Al-Raniry is listed as the Muslim intellectual who played a great contribution to the propagation of Islam in the Malay Archipelago. ${ }^{15}$ The name of al-Raniry itself is perpetuated in Aceh as the name of a public Islamic university. It might be called that the popularity of al-Raniry was the same as Syekh Yusuf in Makassar.

Having met al-Raniry, Syekh Yusuf continued his travel to Yemen. Here, he consistently studying sufism from a number of spiritual persons as well as the leading murshid from different Sufi orders. Through Muhammad Abdul Baqi al-Naqsyabandi, he learned Naqsyabandiah sufi order and from Sayyid Ali al-Zabidi, he studied Ba'alawiyah sufi order and was authorized to teach it. Besides these sufi orders, Syekh Yusuf was also associated with Khalwatiah during his stay in Damascus. He kept in touch with Ahmad Khalwati alQuraishi who was the Khalwatiah leader at Ibnu Arabi's mosque. ${ }^{16}$ The last-mentioned will further influence Syekh Yusuf due to his sufi order called khalwatiah Syekh Yusuf.

${ }^{14}$ Tudjimah, Syekh Yusuf Makasar: Riwayat dan ajarannya (Jakarta: Universitas Indonesia, 1997), p. 125.

${ }^{15}$ Azyumardi Azra, Jaringan Ulama, p. 263.

16 See Martin van Bruinessen, "The Tariqa Khalwatiah in South Celebes", p.254. 
Another popular sufi order that might be relevant to note is Syattariyah. This tariqah is also linked to Ibnu Arabi's teaching like khalwatiah. Syekh Ibrahim al-Kurani was believed as the leading murshid of this sufi order. Syekh Yusuf spent most of his intellectual journey with Syekh Ibrahim al-Kurani. He not only studied regarding Syattariah sufi order, but he also learned many different issues related to Islam. ${ }^{17}$

After spending many years in Arabia, Syekh Yusuf returned to Archipelago in $1670{ }^{18}$ Unfortunately, Syekh Yusuf didn't come back to his home town, Gowa, due to the Gowa kingdom has been taken over by the Dutch colonialist that previously generated Bongaya Treatise in $1667 .{ }^{19} \mathrm{He}$ resided in Banten, where his old frend, Sultan Ageng Tirtayasa ruled the Banten Kingdom (1651-1683). In this regard, Syekh Yusuf became the spiritual advisor of the king Ageng, at the same time, being a son in law of the king. ${ }^{20}$ Besides, Syekh Yusuf along with king Ageng fought against the Dutch

${ }^{17}$ Abdul Kun Ali, “Al-Makassari's (1626-1699) Thought on Insan al-Kamil in 17th Century" Unpublished theses, School of Graduate Studies, UTM Malaysia, 2016.

${ }^{18}$ There is a different perspectives about the year of Syekh Yusuf returning to Archipelago. Some regard that Syekh Yusuf returned in 1664 such as Abu Hamid. Others believed that he arrived in Banten 1670 or 1672 such as Martin and Kerry. See Kerry Ward, Networks of Empire: Forced Migration in the Dutch East India Company (UK: Cambridge University Press, 2009), p. 202.

19 Ahmad Rahman, "Tarekat Sammaniah: Studi tentang Penyebaran dan Ajarannya di Sulawesi Selatan," Disertasi (UIN Syarif Hidayatullah Jakarta, 2007), p. 46.

20 Michael Laffan, The Making of Indonesian Islam, translated by Indi Aunullah, Rini Nurul Badariah, Sejarah Islam di Nusantara (Yogyakarta: Bentang, 2015), p. 22. 
colonialist for many years. Having captured, the king finally surrendered to the colonialists, but Syekh Yusuf with his loyal followers still fought against the Dutch for several weeks. After confronting the Dutch for certain times, Syekh Yusuf was eventually captured by the Dutch in December 1683 and his followers sent out to Gowa. Syekh Yusuf itself was exiled to Ceylon and then removed to the Cape of Good Hope, Capetown, South Africa where he died in 1699. ${ }^{21}$

Based on the description above, it might be considered that Khalwatiah Syekh Yusuf tariqah was not disseminated by Syekh Yusuf itself. This was played by his loyal followers who had been sent out from Banten. More importantly, Khalwatiah Syekh Yusuf is certainly the integration of different tariqah that he had already obtained. In other words, Khalwatiah Syekh Yusuf is not an original work of Syekh Yusuf, but it is the modification of different tariqahs. However, the mixture of different tariqah is a common issue on the tariqah discussion. Each tariqah is normally influenced by other tariqah and the first tariqah certainly colored the following tariqah.

Although Khalwatiah Syekh Yusuf is a mixture of different tariqahs, the author regards that this tariqah has a uniqueness compared to other tariqah. There are, at least, three main issues that need to be taken into account on Khalwatiah Syekh Yusuf. They are inner purity, the concept of God (Allah), and the issue of the human being.

${ }^{21}$ Mustari Mustafa, Agama dan Bayang-Bayang Etis Syekh Yusuf alMakassari (Yogyakarta: LKiS, 2011), p.25. 


\section{Inner Purity}

Generally speaking, the concept of inner purity is characterized by almost tariqah. This is the main vision or the initial foundation among the tariqah followers. Every single follower of tariqah initiated this concept as the first step towards the unity of God. This concept cannot be separated from the way of the human being to treating the world and hereafter. The world, under certain tariqah, is like a knife with a sharp end. It probably can kill the owner of the knife if they cannot control it from its sharp. In this regard, some tariqah treats the world by totally leaving it without taking part in world affairs. They are merely concerned about the hereafter businesses. This is usually called radical ascetic life (zuhud). This type of tariqah might be grouped as an extreme tariqah.

In this sense, Khalwatiah Syekh Yusuf offers a balance between world affairs and the hereafter. This tariqah contends that being a piety Muslim does not mean abandon life in the world but it tried to make a balance for both of them. The world is like a bridge to reach safely in the hereafter. In other words, the joyful life of hereafter strongly depends on the way to behave in the world. If someone commits a good deed in the world, it will certainly have a beautiful life in the hereafter and vice versa. So, making a balance for this different life, as contended by this tariqah, is fundamental for the followers. This is a good strategy to purify the inner thing of the human being. This tariqah stated that every human being has two potentials in terms of temptation. In one hand, human tends to utilize their good temptation. On the other hand, a human 
being might be influenced by their desire to love the world interests. Khalwatiah Syekh Yusuf view that these temptations should be put in a balance. Both of them need to be experienced for the human being. ${ }^{22}$ Therefore, this tariqah might be considered as a moderate tariqah.

Based on this theory, I observed that most of Khalwatiah Syekh Yusuf followers get involved in different types of businesses. Some of them are businessmen, civil servants, government employees, political leaders, lecturers, researchers, and staff in different ministry levels. This can be illustrated that most Khalwatiah Syekh Yusuf tariqah followers consistently perceive that being active in the world's interests can afford their life to financially back up their family life. This issue is crucial for this tariqah. In other words, joining this tariqah does not generate an income unless they get active in the world interests. They also believe that taking part in real life does not diminish their quality of piety. In addition, this involvement may become a strategy to maintain a balance between the world and the hereafter. ${ }^{23}$ However, as far as I observed, the reason behind their engagement with this tariqah is extremely different. Based on my observation for a certain time in 2019, I see some of them are pragmatist followers, they become the followers because they only ask for a higher position in their job environment or hoping to be supported by tariqah followers in a political contest. Once

22 See Abu Hamid, Syekh Yusuf: Seorang Ulama, p. 159.

${ }^{23}$ Interview with Qomar, 46 years old. 
they successfully got the target, they will not concern anymore to tariqah rituals. ${ }^{24}$

In this regard, this tariqah should prepare themselves with a number of inner exercises to control and monitor the desire of human being which is frequently become a strong wall that blocks the clear relation between human and God. These exercises will further purify the inner side of a human being. There are at least three exercises that need to be addressed to create an inner purity among Khalwatiah Syekh Yusuf Tariqah followers. Firsty, the followers need to have positive thinking (husnu al-dhann) either with other people or more importantly to always have a good positive toward God. They believe that by having a good positive to others may become energy to the person in building harmony in real life. Conversely, if someone always has negative in his mind either to God or human, he will be poisoned by these negatives and will regard the others as the enemy of their life. They will not live conveniently in the middle of society. Consequently, their life will not be easier to experience, particularly when he regards God does not support him in daily interests.

Secondly, Khalwatiah Syekh Yusuf encourages his followers to have good conduct (husnul khuluq) in daily life. As contended by Ramli, this is strongly important for the followers to behave well not only for human beings but also for all the creatures. This exercise may be implemented on the way people to speak, to act, and to have a good intention. All

${ }^{24}$ Observation, 2019. 
these ways are expected to respect other people and not to hurt them. The good deed is also symbolized by having a sense of crisis to others and having anger management. However, the Khalwatiah Syekh Yusuf does not mean that people are forbidden to be angry. They believe that anger is an attribute of human beings, so someone must be angry in the right place and right time. Thirdly, the Khalwatiah Syekh Yusuf also called followers to have a good ethic (husnul adab) especially in building good communication between one and others. The human being must follow the guidance from God through his prophet Muhammad saw. In general, the good ethic was exampled by his prophet as the reference for the human being especially being good with the people apart from differences in terms of races, religions, and ethnicities. To put it simply, being a good human means treating another human as a human. This is the core teaching of husnul adab (good ethic). ${ }^{25}$

\section{Concept of God}

Regarding the concept of God, the Khalwatiah Syekh Yusuf believe that God (Allah) who is the One, no one like Him. His essence is not similar with the creature and His being does not depend on the others. He is wajib al-mujud whose existence is not associated with the universe. He is independently the creator of this universe and all the creation depends on Him. That is why all the creatures can be

${ }^{25}$ Interview with Ramli Rasyid, 43 years old. 
identified as the mumkin al-wujud. ${ }^{26}$ According to Khalwatiah Syekh Yusuf, God has attributes that are different from God's essence. For example, this tariqah believes that God is absolutely in power through His attribute not by His essence as Muktazilah's belief. This issue was certainly discussed by classical theology. It is clearly stated that there are differences between Muktazilah school and Asyariah school in terms of the oneness of God. If Muktazilah believes that God has no attributes, Asyariah regards that besides His essence, God also acts with His attributes, not by His essence. So, Asyariah contends that the essence is different from the attributes. ${ }^{27}$ Based on this belief, the author contends that Khalwatiah Syekh Yusuf was influenced by Asyariah theology as the guidance of their principal teaching.

The similarities between Khalwatiah Syekh Yusuf and Asyariah not only viewed with the attributes of God, but the issue of human's conduct also become the topic of this tariqah. Khalwatiah Syekh Yusuf believes that human beings may strive as hard as they can, but God is the last determinant of everything related to human effort. This can be seen in the transcript of Grand Master's (murshid) message to his adherent as follow:

"Make God (Allah swt) as your guide, make an effort to your daily business as hard as you can, make

${ }^{26}$ See Abu Hamid, Syekh Yusuf: Seorang Ulama, p. 173.

${ }^{27}$ Majid Fakhry, A History of Islamic Pbilosophy, diterjemahkan oleh Mulyadi Kertanegara, Sejarah Filsafat Islam (Jakarta: Dunia Pustaka, 1986) p. 286-294. 
stronger to your strive, the output of your effort is not your business, that is God's decision",28

The message of grandmaster (mursyid) to the follower of Khalwatiah Syekh Yusuf as above illustrated that human being need to focus on their daily business. They are encouraged to work as hard as they can before they give their output to God. In other words, Khalwatiah Syekh Yusuf believes God as the absolute determinant for human affairs, but the human being can independently generate the conduct, either he oriented to good or bad. Once people have already made an effort to their business, they may do praying to God through divikr (remembrance to God). That is why the ritual of diikr is frequently held at night because Khalwatiah Syekh Yusuf followers normally work to earn money to support themselves and their families during the day. The diciker performance is usually contested together at the home of grand mursyid, Puang Makka. ${ }^{29}$

Although Syekh Yusuf had studied Syattariyah tariqah which is strongly related to Ibnu Arabi's thought, especially the understanding about wibdat al-mujud (the unity of existence), Syekh Yusuf in his tariqah seemed to carefully adopt the concept of wibdatul wujud. As contended by his followers of this tariqah, they believe that every follower oriented to get closer with God, but not united as Ibnu Arabi's thought. Khalwatiah Syekh Yusuf regards that performing

${ }^{28}$ Interview with Ramli Rasyid, 43 years old.

${ }^{29}$ Interview with Alamsyah Sa'ban Miru, 42 years old. 
driker may lead the followers to get closer with God, particularly when they mention the name of God several times either in a small voice or louder. Performing driker is a compulsory of the followers of Khalwatiah Syekh Yusuf because they believe that doing this may improve their closeness to God and more importantly, drikr is a form of obedience to God. ${ }^{30}$

Due to the different levels of understanding and capabilities to build a strong relationship with God, there are different levels of dzikr among the followers. For the first level, they might be called as the beginners or popularly called bidayah. In this level, tariqah followers usually recite laa ilaaba illa llah (100 times). The second level might be called tawassuth (intermediate). The driker of this level is different from the previous level. Here, they only mention Allah Allah Allah (100 times). The last level is the highest level of followers. It is normally called as khasul khawas (Advanced). This is the peak level of this tariqah where not many followers can achieve it. In performing diqikr, they just recite buwa buwa buwa (100 times). Huwa means He is God. However, 100 times of doing $d z i k r$ at each level might be different from in practical. That is the minimum number, some followers mentioned more than 100 times. Under the Khalwatiah Syekh Yusuf, doing dzikr is not the conduct of the physical sense of human being, but it has come from the inner of heart. ${ }^{31}$ Building a close relationship with God through divikr is one of the strategies

${ }^{30}$ Focus Group Discussion, September 2019.

${ }^{31}$ Observation, October 2019. 
contested with Syekh Yusuf Khalwati. Another principal teaching that might be considered in building a strong relationship with God is understanding the meaning of insan kamil (the perfect human) as follow.

\section{Concept of Insan Kamil}

The concept of insan kamil is a fundamental issue in the context of sufi order discipline. It is a part of the discussion among the Sufis in the history of Islamic thought. This term might be translated as a perfect human. Khalwatiah Syekh Yusuf view that this term derived from the belief that the essence of human being originally from the light of Muhammad (nur Muhammad). ${ }^{32}$ The light of Muhammad is not the prophet Muhammad saw, it is the first creation of God. Nur Mubammad is the main source of the universe. In other words, through nur Muhammad, the universe is created, including the human being. So, sufi activists believe that all the creation contains nur Mubammad entity, especially for the inside of human being. In this sense, the term tajalli (taking place) of God into the universe is becoming the issue. They believe that God takes a place in human being and the human contain nur Mubammad where its source from God. However, this tariqah believes that the process of tajalli does not describe the union between God and human being. ${ }^{33}$ There is

${ }^{32 N a b i l a h ~ L u b i s, ~ M e n y i n g k e a p ~ I n t i s a r i ~ S e g a l a ~ R a h a s i a: ~ S y e k h ~ Y u s u f ~ a l-~}$ Taj al-Makassari (Jakarta: Fakultas Sastra Universitas Indonesia, 1996), p. 158.

${ }^{33}$ Philip K. Hitti, History of the Arabs (New York: Palgrave Macmillah, 2002), p.567-577. 
a separation for both of them, the human being is placed on one side, while God exists on His existence.

Khalwatiah Syekh Yusuf describes nur Mubammad consists of al-labut entity that will embrace the right human being that to be placed. Whoever the human can integrate nur Muhammad in his inner purity that will be called insan kamil (perfect human). In this sense, the perfect human can be described in a perfect way on the prophet Muhammad saw. $\mathrm{He}$ is the perfect example of insan kamil because he can implement al-labut entity in his self. Therefore, there are several arguments to support it, such as mentioned in QS alBaqarah (2) verse 30. In this verse, humans become khalifah representing God's position in the world, and the prophet Muhammad became the perfect representative. Nevertheless, the emergence of insan kamil may exist in any human being as long as they can be a person like a prophet Muhammad saw. Whoever person can act, speak, and have a good intention and tried to follow the tradition of prophet Muhammad saw, they have an opportunity to reach insan kamil

To create another insan kamil, Khalwatiah Syekh Yusuf emphasizes the strategies to achieve it. One strategy which needs to be addressed is how a single person can treat the others under the guidance of the prophet Muhammad saw. In other words, insan kamil does not mean neglecting the relationship between one and others as exampled by Muhammad saw. He focused on two streams of relationship, 
the first one related to God and the last strongly associated with the same human. It is strongly important to note because the human being is a miniature of cosmos where nur Mubammad exists. Therefore, Khalwatiah Syekh Yusuf mainly stresses on the brotherhood, especially for the followers of this tariqah. This issue is crucial for Khalwatiah Syekh Yusuf as stated by the grand mursyid, Puang Makka to his followers: "Whoever you are, as long as you still become the followers of Khalwatiah Syekh Yusuf tariqah, your relationship is like brothers and sisters not only in the world but also in the eternal life after this physical life. Keep an eye on each other! maintain your brotherhood! $!^{34}$

The quotation above illustrated the importance of building brotherhood among human beings. The Khalwatiah Syekh Yusuf highlighted that Insan kamil could not be reached if hurting the feeling of a human being. Nevertheless, the core meaning of insan kamil is decreasing the separator between God and human beings. Being insan kamil is being the closest believer to God.

\section{Conclusion}

Syekh Yusuf generated many heritages that need to be taken into account by the Muslim generation. That heritage is his principal teaching that can be found in his tariqah which is popularly called Khalwatiah Syekh Yusuf. This tariqah is the forefront of sufi orders in South Sulawesi. Khalwatiah Syekh

\footnotetext{
${ }^{34}$ Interview with Alamsyah Sya'ban Miru, 42 years old.
} 
Yusuf has influenced the religious understanding among people in the Celebes region. Although this tariqah was disseminated by Syekh Yusuf adherents, the popularity as well the acceptability of the people toward this tariqah has never ended until recent days. More and more people come to join and become a follower of this tariqah. The motive of visiting the grand mursyid not only asking to become the followers but also some of them asking blessings, especially for politicians who will join the political contest.

Khalwatiah Syekh Yusuf can be grouped as a moderate tariqah due to his principal teachings relate to the Asyariah theology. As can be mentioned that Asyariah theology is another name of ablu Sunnab waljamaah whose theological understanding can be placed as a moderate theology in the history of Islamic thought. The principal teachings of this tariqah such as inner purity, the concept of God, and the meaning of insan kamil also represented the thought of Asyariah theology.

\section{REFERENCES}

Ali, Abdul Kun. "Al-Makassari's (1626-1699) Thought on Insan al-Kamil in $17^{\text {th }}$ Century" Unpublished theses, School of Graduate Studies, UTM Malaysia, 2016.

Azra, Azyumardi. Jaringan Ulama Timur Tengah dan Kepulauan Nusantara Abad XVII dan XVIII: Akar Pembaruan Islam Indonesia. Jakarta: Kencana, 2007. 
Bruinessen, Martin van. "The Origin and Development of Sufi Orders (Tarekat) in Southeast Asia,", Studia Islamika 1: 11994.

Bruinessen, Martin van. "The Tariqa Khalwatiah in South Celebes" in Harry A. Poeze en Pim Schoorl (eds), Excursies in Celebes. Een bundle bijdragen bij het afscheid van J. Noorduyn...(Leiden: KITLV Uitgeverij, 1991.

Bruinessen, Martin van. Kitab Kuning, Pesantren dan Tarekat: Tradisi-Tradisi Islam di Indonesia. Bandung: Mizan, 1995. Erman, Erwiza "Remembering and Forgetting: The History of Syekh Yusuf Struggle for Human Rights", Heritage of Nusantara: International Journal of Religious Literature and Heritage, 1 (1), 2012.

Fakhry, Majid. A History of Islamic Philosophy, diterjemahkan oleh Mulyadi Kertanegara, Sejarah Filsafat Islam. Jakarta: Dunia Pustaka, 1986.

Hamid, Abu. Syekh Yusuf: Seorang Ulama, Sufi dan Pejuang. Jakarta: Yayasan Obor Indonesia, 2005.

Hitti, Philip K. History of the Arabs. New York: Palgrave Macmillah, 2002.

Keraan, Mustapha, Muhammed Haron, "Selected Sufi Texts of Shaykh Yusuf: Translations and Commentaries", Thdskrif Vir Letterkunde, 45 (1), 2008.

Kila, Syahrir. "Syekh Yusuf: Pahlawan Nasional Dua Bangsa Lintas Benua" Walasuji, 9 (2), 2018.

Laffan, Michael. The Making of Indonesian Islam, translated by Indi Aunullah, Rini Nurul Badariah, Sejarah Islam di Nusantara. Yogyakarta: Bentang, 2015. 
Lubis, Nabilah. Menyingkap Intisari Segala Rahasia: Syekh Yusuf al-Taj al-Makassari. Jakarta: Fakultas Sastra Universitas Indonesia, 1996.

Mattulada, Menyusuri Jejak Kehadiran Makassar Dalam Sejarah. Yogyakarta: Ombak, 2011.

Mustafa, Mustari. Agama dan Bayang-Bayang Etis Syekh Yusuf alMakassari. Yogyakarta: LKiS, 2011.

Rahman, Ahmad. "Tarekat Sammaniah: Studi tentang Penyebaran dan Ajarannya di Sulawesi Selatan," Disertasi UIN Syarif Hidayatullah Jakarta, 2007.

Sya'ban, A. Ginanjar "Sanad Syaikh Yusuf al-Makassar atas Tarekat Syaihul Akbar Ibnu Arabi”, unpublished writing, Bogor, 2016.

Tudjimah. Syekb Yusuf Makasar: Riwayat dan ajarannya. Jakarta: Universitas Indonesia, 1997.

Ubaedillah, Achmad. "Khalwatiah Samman Tarekat in South Sulawesi, Indonesia (1920-1998): Exercising Authority in an Era of Change," Asian Journal of Social Science, 24: 2 (2014).

Ward, Kerry. Networks of Empire: Forced Migration in the Dutch East India Company. UK: Cambridge University Press, 2009.

\section{Interview}

Alamsyah Sa'ban Miru, 42 years old.

Qomar, 46 years old.

Ramli Rasyid, 43 years old. 